\title{
PENENTUAN FORMULASI TEPUNG DAN EKSTRAK INULIN UMBI DAHLIA TERHADAP MAKANAN FUNGSIONAL BUBUR INSTAN BERAS PANDANWANGI
}

\author{
Oleh : \\ Riza Trihaditia**) \\ Tammy Tri Sundayati*)
}

\begin{abstract}
Abstrak
Makanan fungsional merupakan salah satu pangan yang memiliki nilai fungsi yang tinggi namun selalu lemah dalam aspek organoleptik. Salah satu makanan fungsional yang dapat dikembangkan adalah bubur instan beras Pandanwangi berfortifikasi. Fortifikan yang dapat ditambahkan dalam bubur instan beras Pandanwangi adalah inulin yang berasal dari tanaman umbi dahlia. Tujuan dari penelitian ini adalah untuk mengetahui formulasi optimal yang akan diminati panelis. Penelitian ini bersifat eksperimental yang memanfaatkan umbi dahlia sebagai bahan utama dan beras Pandanwangi sebagai bahan dasar dengan menggunakan 4 variasi formula yang diuji menggunakan RSM (Response Surface Methode). Formula 1 (F1): beras Pandanwangi +10 g tepung umbi dahlia, F2: beras Pandanwangi, F3: beras Pandanwangi $+10 \mathrm{~g}$ ekstrak inulin, dan F4: beras Pandanwangi $+5 \mathrm{~g}$ tepung umbi dahlia +5 g ekstrak inulin. Pengujian organoleptik dilakukan oleh 24 orang panelis tidak terlatih dan 1 orang panelis ahli dengan parameter pengujian terdiri dari warna, rasa, aroma dan, tekstur. Hasil penelitian ini menunjukkan bahwa makanan fungsional berupa bubur instan beras Pandanwangi dengan penambahan umbi dahlia dalam bentuk tepung (F1) merupakan formula yang paling diminati panelis.
\end{abstract}

Kata kunci: Inulin, Umbi Dahlia, Bubur Beras Instan, Pandanwangi, Makanan Fungsional.

\begin{abstract}
Functional foods is one of the food that has a high function value but it is always weak in organoleptic aspects. One of the functional foods that can be developed is instant Pandanwangi rice porridge. The fortificant that can be added to instant Pandanwangi rice porridge is inulin from dablia tubers. The purpose of this research were to determine the optimal formulation received by panelists. These study was experimental by using the tuber of dablia as the main ingredients and Pandanwangi rice as a basic ingredients with using four formula variations processed using RSM (Respons Surface Method). Formula 1 (F1): Pandanwangi rice + $10 \mathrm{~g}$ of dablia tuber flour, F2: Pandanwangi rice, F3: Pandanwangi rice $+10 \mathrm{~g}$ of inulin extract, F4: Pandanwangi rice $+5 \mathrm{~g}$ of dablia tuber flour $+5 \mathrm{~g}$ of inulin extract. Organoleptic testing conducted by 24 untrained panelists and one expert panelist with color, taste, flavor, and texture as parameters. The results of these study indicated that functional foods of instant Pandanwangi rice porridge with added dablia tuber in flour (F1) was the optimal formula the panelists received.
\end{abstract}

Keywords: Inulin, Dablia Tubers, Instant Porridge, Pandanwangi, Functional Foods.

*) Alumni Fakultas Sains Terapan UNSUR

**) Dosen Fakultas Sains Terapan UNSUR

PENENTUAN FORMULASI TEPUNG DAN

EKSTRAK INULIN UMBI DAHLIA

RIZA TRIHADITIA dan TAMMY TRI SUNDAYATI

TERHADAP MAKANAN FUNGSIONAL

BUBUR INSTAN BERAS PANDANWANGI 


\section{PENDAHULUAN}

Padi (Oryza sativa L.) merupakan salah satu tanaman pangan paling penting di dunia. Hal ini karena beras masih menjadi sumber makanan pokok bagi sebagian besar penduduk dunia terutama wilayah Asia termasuk negara Indonesia. Hal ini menjadikan tingkat ketergantungan masyarakat Indonesia terhadap beras semakin hari semakin meningkat. Sementara itu, sifat manusia yang mudah bosan dengan apapun termasuk pada jenis pangan membuat keberagaman pangan perlu dilakukan. Salah satu bentuk variasi olahan makanan dari beras yang mudah dikonsumsi adalah bubur. Selain umum dijadikan sebagai menu sarapan, bubur juga seringkali dijadikan menu saat sakit karena memiliki tekstur yang lembut sehingga mudah untuk dikonsumsi. Namun, proses pembuatan bubur beras yang membutuhkan waktu cukup lama dianggap tidak praktis bagi sebagian orang.

Di Indonesia sendiri sudah terdapat bubur beras instan yang dijual dipasaran, namun produk tersebut belum disertai dengan penambahan zat gizi secara spesifik atau biasa disebut dengan fortifikasi. Salah satu nutrien yang dapat ditambahkan dalam produk pangan adalah prebiotik. Salah satu contoh prebiotik alami yang saat ini terus dikembangkan adalah inulin. Inulin yaitu suatu bahan pangan yang masuk dalam kategori prebiotik dimana sifatnya tidak dapat dicerna oleh inang melainkan difermentasi selektif oleh beberapa mikroflora kolon (Sundari, 2014).

Di Indonesia, pemberian prebiotik dari inulin telah diberlakukan pada beberapa produk pangan seperti susu, biskuit atau makanan bayi. Namun sejauh ini belum ditemukan pada produk makanan pokok seperti pada bubur beras instan. Pengembangan produk pangan berupa bubur beras instan dengan fortifikasi inulin dari umbi dahlia dapat menjadi alternatif makanan cepat saji yang baik bagi keseshatan serta pilihan alternatif produk pangan fungsional.

Pemilihan umbi dahlia sebagai sumber inulin adalah karena kandungan inulin yang lebih tinggi dibandingkan dengan tanaman lokal lainnya. Berdasarkan penelitian yang dilakukan oleh Mangunwidjaja (2014) umbi dahlia mengandung inulin sebesar $80.09 \%$ sedangkan tanaman lokal lainnya yaitu gembili, turubuk dan bonggol pisang memiliki kadar inulin masing-masing $4.02 \%, 0.23 \%$, dan $1.16 \%$. Selain itu, pemilihan jenis beras menjadi salah satu komponen penting dalam pengolahan bubur beras. Dalam penelitian ini beras dari varietas lokal Pandanwangi dipilih selain karena memiliki aroma pandan alami yang dapat meningkatkan citarasa juga sebagai upaya dalam memberdayakan produk lokal khas Cianjur.

Berdasarkan latar belakang tesebut, penulis melakukan penelitian tentang makanan fungsional berupa bubur beras Pandanwangi instan yang diolah dengan penambahan inulin dari umbi dahlia dengan tujuan untuk mengetahui formula bubur instan beras Pandanwangi berfortifikasi yang dapat diterima oleh konsumen dan mengetahui respon optimum uji organoleptik bubur instan beras Pandanwangi berfortifikasi sebagai produk pangan fungsional.

\section{METODE PENELITIAN}

Penelitian ini dilaksanakan pada bulan Februari sampai dengan April 2019 di Laboratorium Virologi Balai Tanaman Hias (Balithi) Sagunung Pacet Cianjur dan Laboratorium Pangan Fakultas Sains Terapan Universitas Suryakancana Cianjur.

Penelitian ini merupakan penelitian eksperimental berdasarkan metode yang dilakukan peneliti sebelumnya namun dengan modifikasi sehingga memerlukan penelitian pendahuluan. Penelitian pendahuluan tersebut meliputi penetapan prosedur pembuatan tepung dan ekstrak umbi dahlia juga prosedur pembuatan 
bubur beras Pandanwangi instan untuk menetapkan metode yang akan digunakan untuk membuat formula yang akan dilakukan pengujian organoleptik pada penelitian utama.

\section{Alat dan Bahan}

Bahan baku utama yang digunakan adalah beras Pandanwangi dan umbi dahlia yang diambil dari daerah Cipanas Kabupaten Cianjur. Bahan-bahan lain yang digunakan yaitu air, etanol $96 \%$ dan aquades. Alat-alat yang digunakan pada penelitian ini meliputi alat untuk pembuatan tepung dan ekstrak umbi dahlia serta pembuatan bubur beras Pandanwangi instan antara lain pisau, wadah, oven, chopper, kertas saring, corong pemisah, ayakan, neraca, gelas ukur, panci, kompor, blender dan tempat pendingin.

\section{Penelitian Pendahuluan}

1. Pengolahan Umbi Dahlia dalam Bentuk Tepung

Umbi dahlia yang dibuat menjadi tepung murni dilakukan berdasarkan metode yang dilakukan oleh Widowati (2009) yaitu umbi dahlia dibersihkan dari kotoran seperti tanah lalu dicuci menggunakan air mengalir, kemudian diparut. Parutan umbi dahlia dikeringkan dalam oven menggunakan suhu $80^{\circ} \mathrm{C}$ selama 45 menit. Umbi yang telah kering dihaluskan dan diayak sampai menjadi tepung.

2. Pengolahan Umbi Dahlia dalam Menghasilkan Ekstrak Inulin

Ekstraksi inulin dilakukan berdasarkan metode yang dilakukan Desfitri et al. (2017). Umbi dahlia yang telah dibersihkan kemudian dipotong dan diblender dengan penambahan air 1:1. Pisahkan ampas dan ekstraknya. Ekstrak atau filtrat dilarutkan dengan penambahan etanol 96\% dengan perbandingan 1:3 dari volume filtrat. Larutan disimpan selama \pm 17 jam hingga terdapat endapan. Endapan tersebut merupakan inulin basah yang selanjutnya ditimbang dan kemudian dikeringkan menggunkan oven $80^{\circ} \mathrm{C}$ selama \pm 1 jam. Setelah kering esktrak inulin umbi dahlia dihaluskan menjadi serbuk inulin. 3. Pembuatan bubur instan beras
Pandanwangi

Cuci beras kemudian rendam selama $1 \mathrm{jam}$. Beras dimasak dengan air (1:4) lalu masukan bahan fortifikan saat setengah masak dan aduk kembali sampai benar-benar mengental lalu dinginkan dalam suhu ruang. Tuang bubur dalam loyang dan ratakan. Keringkan dalam oven dengan suhu $80^{\circ} \mathrm{C}$ selama kurang lebih 6 jam. Bubur yang kering ditumbuk kasar sampai berbentuk serpihan tipis.

\section{Rancangan Eksperimen}

Rancangan eksperimen dalam penelitian ini dibuat 4 formula yaitu:

Formula 1: Bubur beras instan Pandanwangi dengan $10 \mathrm{~g}$ tepung umbi dahlia

Formula 2: Bubur instan beras Pandanwangi tanpa fortifikasi

Formula 3: Bubur instan beras Pandanwangi dengan $10 \mathrm{~g}$ ekstrak inulin

Formula 4: Bubur instan beras Pandanwangi dengan $5 \mathrm{~g}$ tepung umbi dahlia dan $5 \mathrm{~g}$ ekstrak inulin.

Variabel penelitian ini adalah preferensi terhadap warna, aroma, tekstur dan rasa. Warna merupakan komponen yang sangat penting untuk menentukan kualitas atau derajat penerimaan suatu bahan pangan (Irmayanti et al., 2017). Sedangkan untuk aroma, Midayanto dan Yuwono (2014) berpendapat jika aroma dapat menentukan kelezatan suatu bahan pangan, sehingga umumnya seseorang dapat menilai lezat tidaknya suatu bahan makanan dengan mencium aroma bahan pangan tersebut. Tekstur menurut Trihaditia (2015) adalah sensasi tekanan yang dapat diamati dengan mulut pada waktu ditelan dan rasa menurut Palupi (2015) berhubungan dengan komponen bahan yang ditangkap oleh indera perasa yaitu lidah dan merupakan salah satu penentu dalam tingkat penerimaan panelis. 
Bubur dengan masing-masing formula akan diuji menggunakan uji organoleptik metode Hedonic Test dengan jumlah panelis sebanyak 25 orang terdiri dari 24 panelis tidak terlatih dan 1 orang panelis ahli. Panelis dibagikan form kuisioner uji organoleptik dan produk Bubur Instan Beras Pandanwangi secara acak. Setelah itu panelis akan menilai berdasarkan tingkat kesukaan produk.

Data akan diolah menggunakan RSM (Response Surface Methode). Menurut Radojkovic et al. (2012) RSM adalah kumpulan statistik dan matematika teknik yang berfungsi untuk mengembangkan, meningkatkan, dan mengoptimalkan proses, dimana respon dipengaruhi oleh beberapa faktor (variabel independen). Menurut Trihaditia (2015) tujuan dari metode RSM adalah untuk mencari respons optimum dengan cara mencari tempuhan titik tengah dan tempuhan lengan bintang (star arm runs).

\section{HASIL DAN PEMBAHASAN}

\section{Penelitian Pendahuluan}

Pada penelitian ini dilakukan uji pendahuluan untuk menentukan metode yang tepat untuk mendukung produk yang akan dilakukan pada pengujian mutu organoleptik. Penelitian pendahuluan diawali dengan uji coba pembuatan tepung umbi dahlia dengan dua metode yang berbeda yaitu potongan umbi yang dikeringkan (a) dan parutan umbi yang dikeringkan (b). Kedua metode tersebut dilakukan menggunakan bobot umbi yang sama yaitu $500 \mathrm{~g}$ berat segar dengan suhu pengeringan sebesar $80^{\circ} \mathrm{C}$.

Pada metode pertama (a) umbi yang telah dicuci bersih dan dipotong kemudian dikeringkan dalam oven. Pada metode ini dibutuhkan waktu pengeringan yang cukup lama sekitar 90 menit karena banyaknya kandungan air yang harus dihilangkan sampai umbi benar-benar kering. Hal ini karena berdasarkan penelitian yang dilakukan oleh Mangunwidjaja et al. (2014) bahwa umbi dahlia merupakan tanaman dengan kandungan air yang banyak yaitu sebesar $79.90 \%$. Sedangkan pada metode ke-dua (b), meskipun umbi mengandung banyak air, karena umbi terlebih dahulu dilakukan pemarutan dan pemerasan, maka pengeringan umbi relatif lebih cepat yaitu sekitar 45 menit.

Selain waktu pengeringan, perbedaan kedua metode tersebut juga memberikan pengaruh terhadap warna dan tekstur tepung. Pada metode (a) tepung berwarna cokelat gelap dengan tekstur yang cukup kasar. Hal ini karena lamanya waktu pengeringan membuat warna tepung menjadi lebih gelap. Potongan umbi yang tidak sama pada saat dikeringkan juga membuat umbi tidak kering secara bersamaan. Selain itu, beberapa potongan umbi yang berukuran besar dan terlalu kering sulit dihaluskan sehingga tidak dapat diayak menjadi tepung.

Berbeda dengan potongan umbi, tepung yang lebih dahulu diparut dan diperas airnya (b) memiliki warna tepung yang lebih pucat seperti kuning kecoklatan dengan tekstur relatif halus. Parutan umbi yang telah kering memiliki tekstur kasar namun rapuh sehingga lebih mudah dihaluskan dan umbi yang terbuangpun hanya sedikit.

Tabel 1. Hasil Percobaan Penepungan Umbi Dahlia.

\begin{tabular}{lcc}
\hline \multicolumn{1}{c}{ Parameter } & Metode & \\
\hline Bobot awal setelah dikupas $(\mathrm{g})$ & Dipotong & Diparut \\
Suhu (Celcius) & 500 & 500 \\
Waktu pengeringan (menit) & 80 & 80 \\
Bobot tepung umbi (g) & 90 & 45 \\
\hline
\end{tabular}

Sumber: Data primer (olahan) (2019). 
Berdasarkan hasil akhir penepungan, umbi yang diparut terlebih dahulu sebelum dikeringkan memiliki warna dan tekstur yang lebih baik. Oleh karena itu dalam proses pembuatan selanjutnya digunakan parutan umbi dahlia yang telah ditepungkan sebagai salah satu bahan formulasi bubur instan beras Pandanwangi berfortifikasi.

Setelah pembuatan tepung, penelitian pendahuluan berlanjut pada penentuan metode ekstraksi inulin umbi dahlia. Percobaan pertama dilakukan berdasarkan penelitian Widowati (2005) yaitu menggunakan umbi dahlia dengan bobot $500 \mathrm{~g}$ berat segar dengan penambahan air 1:2 (b:v), sedangkan pada percobaan kedua dan ketiga percobaan dilakukan berdasarkan penelitian Desfitri et al. (2017) yang telah dimodifikasi. Percobaan kedua menggunakan umbi dahlia dengan bobot $300 \mathrm{~g}$ berat segar dan percobaan ketiga menggunakan $400 \mathrm{~g}$ berat segar dengan masing-masing umbi ditambahkan air sebanyak 1:1 (b:v).

Tabel 2. Hasil Percobaan Ekstraksi Inulin Umbi Dahlia

\begin{tabular}{lccc}
\hline \multicolumn{1}{c}{ Keterangan } & A & B & C \\
\hline Bobot awal setelah dikupas (g) & 500 & 300 & 400 \\
Air (b:v) & $1: 2$ & $1: 1$ & $1: 1$ \\
Etanol (\%) & 40 & 96 & 96 \\
Banyaknya pelarut (v:v) & $2: 5$ & $1: 3$ & $1: 3$ \\
Waktu pengendapan (jam) & 15 & 21 & 17 \\
Tepung Inulin (g) & 2 & 4 & 15 \\
\hline
\end{tabular}

Sumber: Data primer (olahan) (2019).

Dari tabel diatas, dapat diketahui bahwa persentase etanol dan waktu pengendapan berpengaruh terhadap banyaknya endapan inulin yang dihasilkan. Pada percobaan pertama, sari umbi yang dilarutkan menggunakan etanol $40 \%$ sebanyak 2:5 (v:v) dengan waktu pengendapan selama 15 jam hanya menghasilkan tepung ekstrak inulin sebanyak 2 g. Sedangkan pada percobaan kedua dan ketiga yang menambahkan etanol masing-masing sebanyak 1:3 (v:v) dari volume sari umbi memberikan hasil yang lebih baik dari percobaan pertama.

Pada percobaan kedua, ekstrak umbi dahlia dilarutkan menggunakan etanol 96\% dengan waktu pengendapan selama 21 jam dan mendapatkan hasil tepung ekstrak inulin sebanyak $4 \mathrm{~g}$. Dengan selisih $100 \mathrm{~g}$ bobot umbi dahlia, percobaan ketiga yang juga dilarutkan dengan etanol 96\% mendapat hasil $3 \mathrm{kali}$ lipat lebih banyak tepung ekstrak inulin umbi dahlia yaitu sebanyak $15 \mathrm{~g}$ dengan waktu pengendapan selama $17 \mathrm{jam}$. Hal ini karena menurut Desfitri et al. (2017) semakin tinggi pelarut maka semakin tinggi pula endapan yang dihasilkan dan semakin banyak pelarut yang digunakan maka kemampuan mengekstrak inulin pun semakin tinggi. Sedangkan semakin lama waktu pengendapan maka perolehan endapan inulin semakin sedikit. Oleh karena itu, dalam proses pembuatan selanjutnya digunakan ekstrak inulin dengan etanol $96 \%$ yang diendapkan selama 17 jam untuk salah satu bahan formulasi bubur instan beras Pandanwangi berfortifikasi.

Penelitian pendahuluan terakhir yang dilakukan pada tahap ini adalah pembuatan bubur beras Pandanwangi dalam bentuk instan. Beras Pandanwangi yang telah dimasak menjadi bubur kemudian dikeringan untuk mengurangi kadar air sehingga memiliki daya simpan yang lebih panjang. Menurut Estiasih dan Ahmadi (2009) pengeringan memiliki beberapa tujuan seperti untuk mendapatkan produk pangan yang stabil sesuai dengan penggunaan produk tersebut dan karakteristik sensoris tertentu, mengurangi volume dan berat produk, serta sebagai diversifikasi produk seperti inovasi pada produk sereal instan dan minuman instan. 
Pada proses instanisasi bubur beras ini dilakukan menggunakan metode konduksi yaitu bahan panas kontak dengan plat panas dalam hal ini adalah oven pengering yang diatur sampai suhu $80^{\circ} \mathrm{C}$. Bubur yang telah kering akan membentuk lapisan-lapisan tipis. Pada percobaan pertama, lapisan tipis bubur dihaluskan dengan blender. Hasil yang didapat ketika ditambahkan air, bubur bertekstur terlalu lembut seperti bubur bayi. Karena bubur instan ini ditujukan untuk semua kalangan usia, maka dibuat percobaan kedua yaitu bubur yang telah kering tidak dihaluskan melainkan ditumbuk secara kasar. Hasil yang didapat bubur instan memiliki tekstur butiran halus seperti pada bubur beras biasa, oleh karena itu bubur yang ditumbuk kasar akan digunakan dalam pengujian mutu organoleptik bubur instan beras Pandanwangi berfortifikasi.

\section{Penelitian Utama}

a. Warna

Setelah membuat model desain penelitian parameter warna, tahapan selanjutnya adalah melakukan perhitungan Central Composite Design dan didapatkan hasil sebagai berikut:

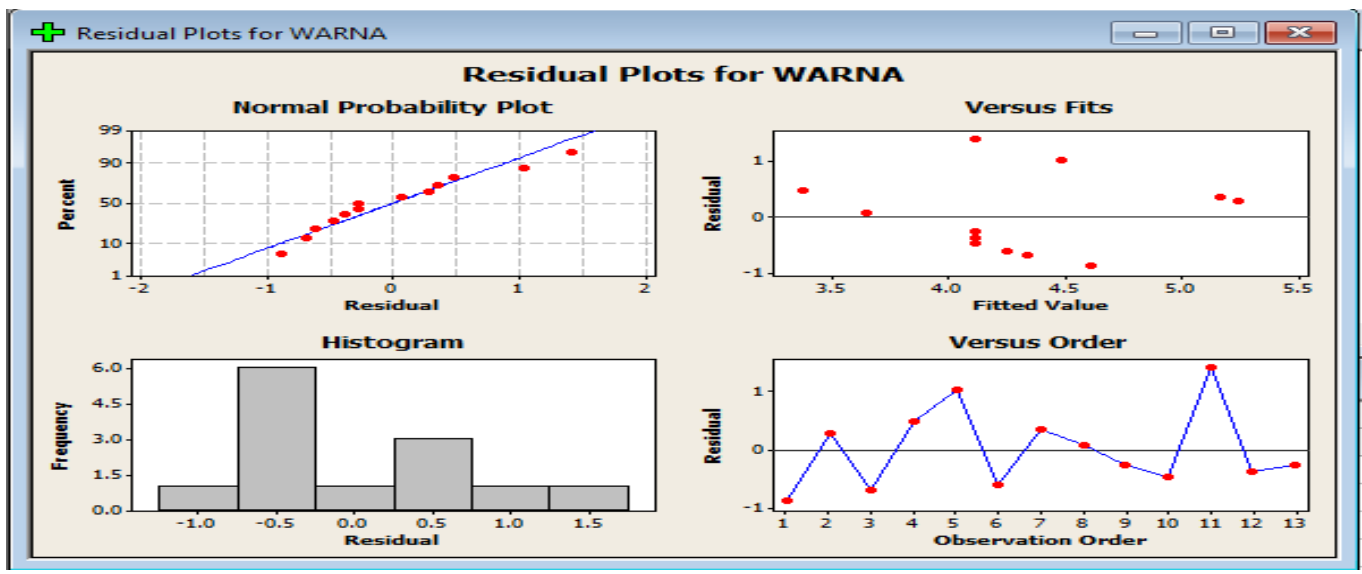

Gambar 1. Grafik perhitungan anova dari parameter warna.

Berdasarkan gambar diatas dapat diketahui bahwa sebaran data untuk warna tersebar dengan rata dan mempunyai normal probability yang baik dimana titik-titik data terebut mendekati kegaris normal probability sehingga dapat dilakukan perhitungan selanjutnya.

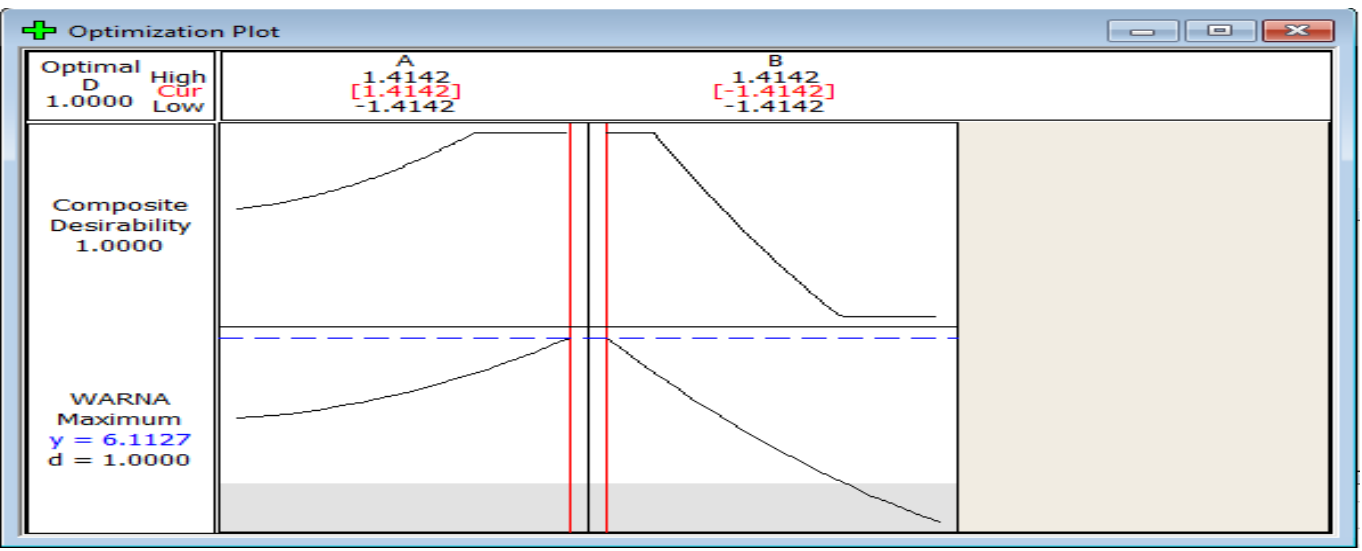

Gambar 2. Nilai optimasi dari parameter warna (Data primer tahun 2019).

Perhitungan optimasi untuk Gambar 2 menunjukkan nilai warna akan optimal pada nilai 6.1127, dimana akan membentuk suatu parabola yang terbuka kebawah dan mencirikan warna tersebut mempunyai nilai optimal. Nilai fungsi 
desirability pada warna berada pada skala diterima oleh panelis. 1.0 menunjukkan angka yang dapat

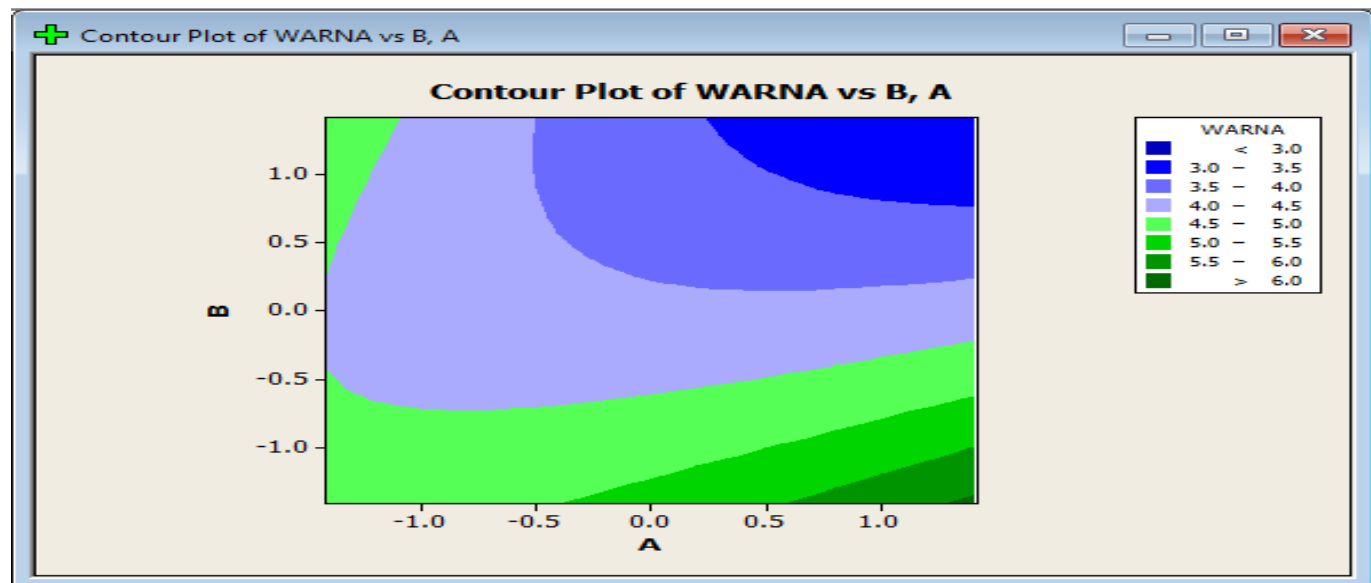

Gambar 3. Contour plot dari parameter warna (Data primer tahun 2019).

Dari Gambar 3 dapat diketahui bahwa batasan wilayah nilai optimasi pada warna adalah diantara 3.0-6.0. Penentuan wilayah optimasi tersebut dapat dipresentasikan dalam bentuk 3D.

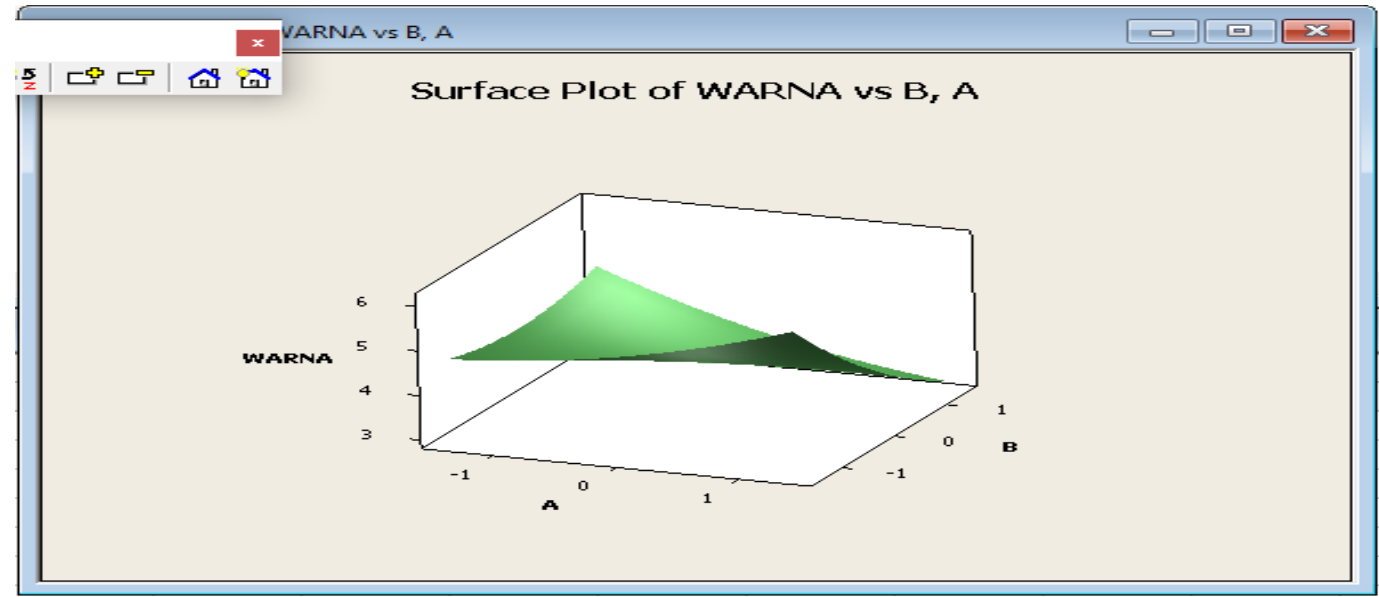

Gambar 4. Surface plot dari parameter (Data primer tahun 2019).

Dari gambar countour plot warna, akan didapatkan optimasi berdasarkan Tabel 3. Wilayah Optimasi Rata-Rata Warna.

\begin{tabular}{cc}
\hline Wilayah Optimasi & Rata-Rata Warna \\
\hline 1 & $>6.0$ \\
2 & $5.5-6.0$ \\
3 & $5.0-5.5$ \\
4 & $4.5-5.0$ \\
5 & $4.0-4.5$ \\
6 & $3.5-4.0$ \\
7 & $3.0-3.5$ \\
8 & $<3.0$ \\
\hline
\end{tabular}

nilai rata-rata sampel. Batasan wilayah dapat dilihat pada Tabel 3.

Sumber: Data primer (olahan) (2019). 
Untuk mendapatkan nilai optimal dari berbagai jenis sampel yang digunakan, maka nilai rata-rata sampel tersebut akan

Tabel 4. Nilai Optimasi Rata-Rata Warna.

\begin{tabular}{ccc}
\hline Sampel & Rata-Rata & Wilayah Optimasi \\
\hline F1 & 3.72 & 6 \\
F2 & 5.52 & 3 \\
F3 & 3.64 & 6 \\
F4 & 3.84 & 6 \\
\hline
\end{tabular}

Sumber: Data primer (olahan) (2019).

*Keterangan:

F1: Beras PW $+10 \mathrm{~g}$ Tepung Umbi

F2: Beras PW

F3: Beras PW + $10 \mathrm{~g}$ Ekstrak Inulin

F4: Beras PW $+5 \mathrm{~g}$ Tepung Umbi $+5 \mathrm{~g}$ Ekstrak Inulin

Dari tabel di atas dapat diketahui bahwa sampel dengan F1 (Beras Pandanwangi $+10 \mathrm{~g}$ Tepung Umbi), F3 (Beras Pandanwangi $+10 \mathrm{~g}$ Ekstrak Inulin) dan F4 (Beras Pandanwangi $+5 \mathrm{~g}$ Tepung Umbi dan 5 g Ekstrak Inulin) berada pada wilayah optimasi 6 . Sedangkan untuk F2 (Beras Pandanwangi) berada pada wilayah optimasi 3. Sampel terbaik untuk nilai optimasi warna adalah F2 dikarenakan sampel tersebut berada di wilayah tertinggi yaitu wilayah optimasi 3 yang posisinya lebih tinggi dibandingkan formulasi lainnya.

Hasil uji kesukaan terhadap warna menunjukkan bahwa penambahan umbi dahlia baik berupa tepung maupun ekstrak menurunkan kesukaan terhadap warna bubur beras dibandingkan dengan bubur beras tanpa fortifikan. Hal ini diduga karena persepsi panelis terhadap bubur beras adalah berwarna putih bersih seperti pada formula F2. Sedangkan pada formula F1, F3, dan F4 memiliki warna kecoklatan sehingga dianggap panelis tidak menarik.

Formulasi bubur beras yang ditambahkan umbi dahlia baik berupa tepung maupun ekstrak menghasilkan warna kecoklatan. Hal ini disebabkan oleh adanya proses browning non enzimatis (maillard). Reaksi maillard merupakan reaksi terjadi antara senyawa karbohidrat dimasukan kedalam plot wilayah optimasi dari berbagai sampel tersebut dapat dilihat pada Tabel 4. dengan gugus amina primer, reaksinya dapat menyebabkan terbentuknya pigmen berwarna coklat, pigmen tersebut pigmen melanodin. Reaksinya diawali dengan reaksi antara gugus keton aldehid pada gula bereaksi dengan asam amino pada protein sehingga membentuk senyawa glukosilamin. Selain itu juga ada beberapa faktor yang mempengaruhi reaksi millard diantaranya suhu, kadar karbohidrat, kadar protein, tingkat keasaman, dan tipe gula/karboidrat.

Berdasarkan penelitian yang dilakukan oleh Mangunwidjaja et al. (2014) umbi dahlia mengandung karbohidrat sebesar $80.80 \%$ dan protein $5.92 \%$. Dari penelitian tersebut menunjukkan umbi dahlia tinggi akan karbohidrat sehingga akan mendukung proses terjadinya maillard. Oleh karena itu, dapat dikatakan bahwa penampilan fisik bubur instan beras Pandanwangi yang tidak sesuai dengan persepsi panelis mengurangi nilai ketertarikan terhadap produk.

b. Rasa

Setelah membuat model desain penelitian parameter warna, tahapan selanjutnya adalah melakukan perhitungan Central Composite Design dan didapatkan grafik seperti berikut: 


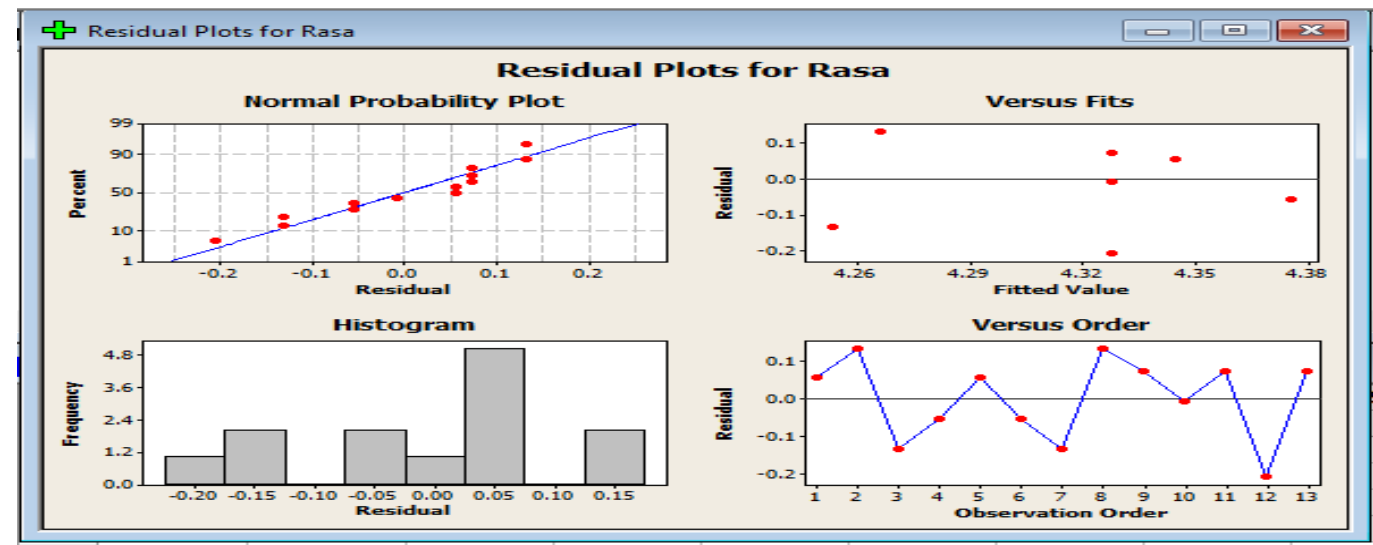

Gambar 5. Grafik perhitungan anova dari parameter rasa.

Berdasarkan grafik diatas dapat diketahui bahwa sebaran data untuk rasa tersebar rata karena titik-titik data tersebut

mendekati kegaris normal probability. Untuk itu, data dapat dilakukan perhitungan selanjutnya.

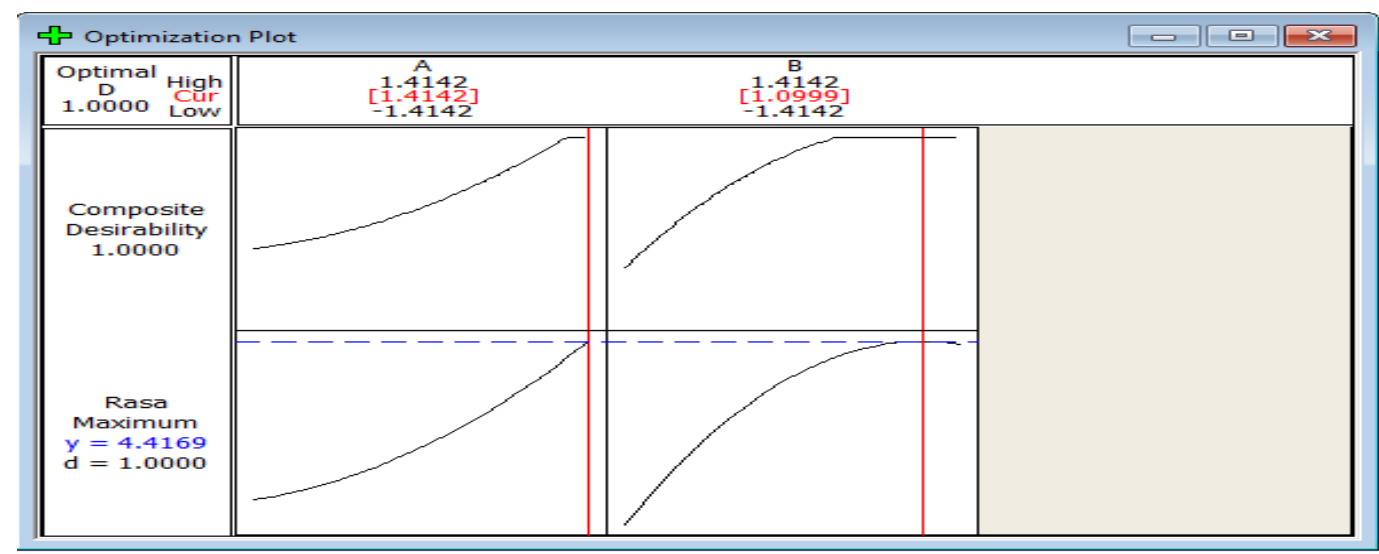

Gambar 6. Nilai optimasi dari parameter rasa.

Perhitungan optimasi untuk Gambar 6 didapatkan nilai rasa akan optimal pada nilai 4.4169, dimana akan membentuk suatu parabola yang terbuka kebawah dan mencirikan rasa tersebut mempunyai nilai optimal. Fungsi desirability menujukan nilai 1.0 yaitu nilai optimasi rasa dapat dikatakan baik. Penentuan daerah optimasi dapat dilakukan dengan Contour dan Surface.

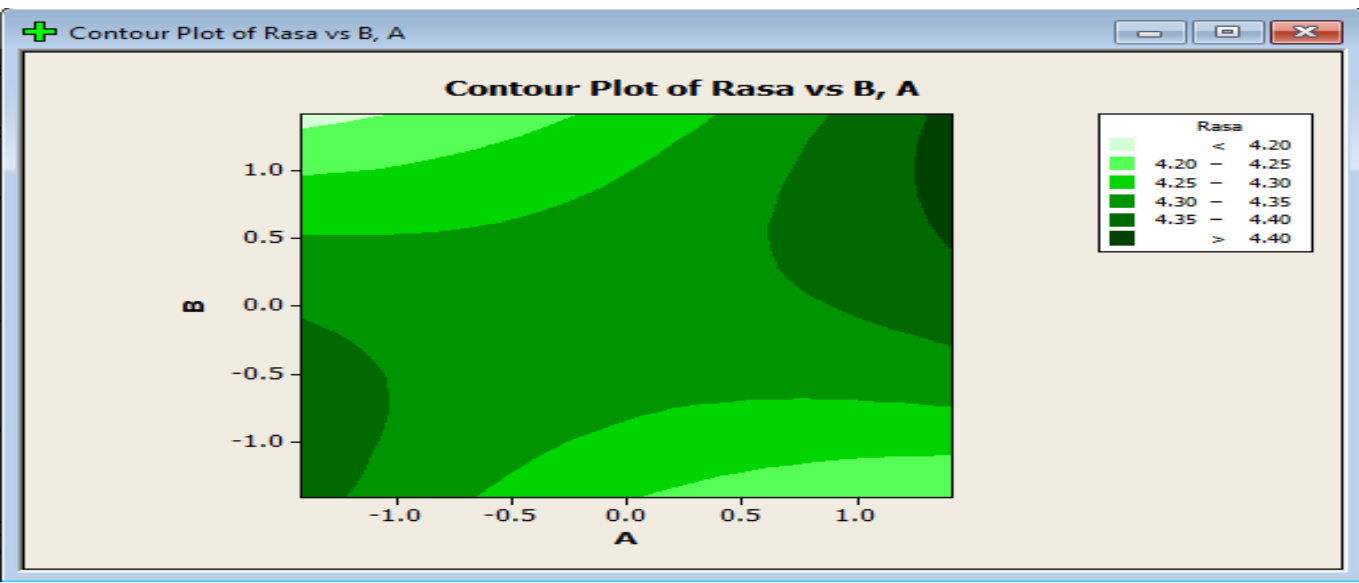

Gambar 7. Contour plot dari parameter rasa (Data primer tahun 2019). 
Grafik diatas menunjukkan batasan wilayah nilai optimasi pada rasa berada diantara 4.20-4.40 dengan presentasi bentuk 3D seperti berikut:

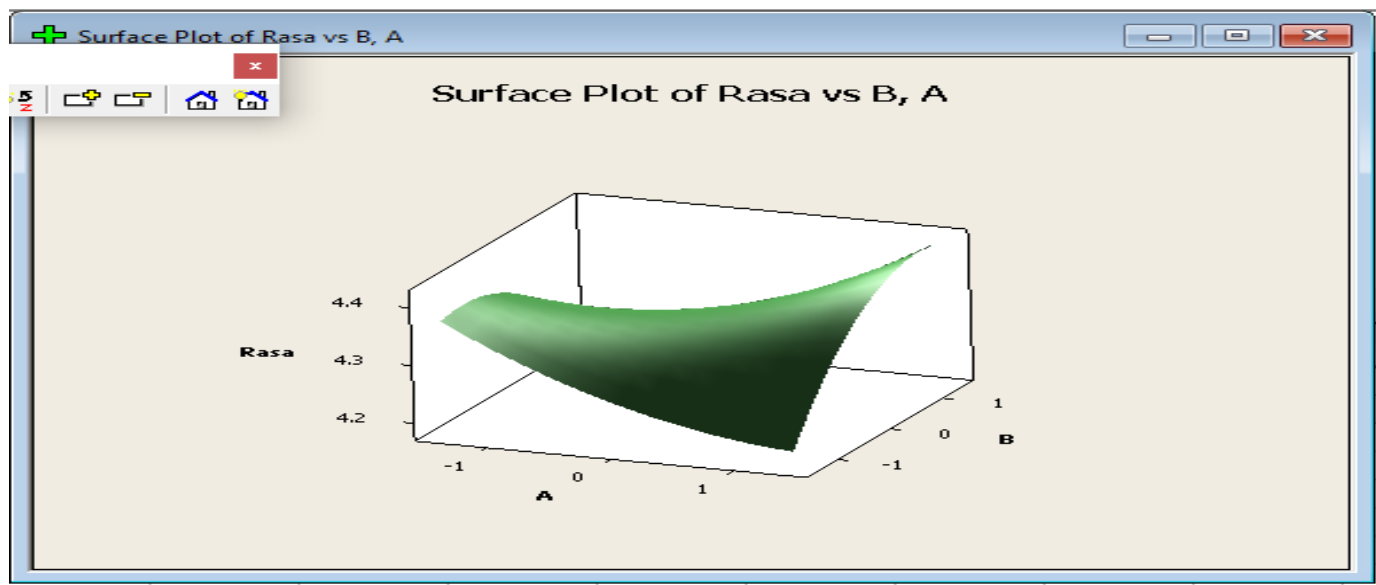

Gambar 8. Surface plot dari parameter rasa (Data primer tahun 2019).

Dari gambar contour, dapat berdasarkan nilai rata-rata sampel ditentukan wilayah optimasi sebagai berikut:

Tabel 5. Wilayah Optimasi Rata-Rata Rasa.

\begin{tabular}{cc}
\hline Wilayah Optimasi & Rata-Rata Rasa \\
\hline 1 & $>4.40$ \\
2 & $4.35-4.40$ \\
3 & $4.30-4.35$ \\
4 & $4.25-4.30$ \\
5 & $4.20-4.25$ \\
6 & $<4.20$ \\
\hline
\end{tabular}

Sumber: Data primer (olahan) tahun 2019.

Untuk mendapatkan nilai optimal dari berbagai jenis sampel yang digunakan, maka nilai rata-rata sampel tersebut dimasukan kedalam plot wilayah optimasi dari berbagai sampel tersebut dan hasil dapat dilihat pada Tabel 6.

Tabel 6. Nilai Optimasi Rata-Rata Rasa.

\begin{tabular}{ccc}
\hline Sampel & Rata-Rata & Wilayah Optimasi \\
\hline F1 & 4.40 & 2 \\
F2 & 4.40 & 2 \\
F3 & 4.12 & 6 \\
F4 & 4.32 & 3 \\
\hline
\end{tabular}

Sumber: Data primer (olahan) tahun 2019.

*Keterangan:

F1: Beras PW + $10 \mathrm{~g}$ Tepung Umbi

F2: Beras PW

F3: Beras PW + $10 \mathrm{~g}$ Ekstrak Inulin

F4: Beras PW $+5 \mathrm{~g}$ Tepung Umbi $+5 \mathrm{~g}$ Ekstrak Inulin

Dari Tabel 6 dapat diketahui bahwa sampel F1 (Beras Pandanwangi $+10 \mathrm{~g}$ Tepung Umbi) dan F2 (Beras Pandanwangi) berada pada wilayah optimasi 2. Untuk F3 (Beras Pandanwangi $+10 \mathrm{~g}$ Ekstrak Inulin) berada pada wilayah optimasi 6 dan F4 (Beras Pandanwangi $+5 \mathrm{~g}$ Tepung Umbi $+5 \mathrm{~g}$ 
Ekstrak Inulin) pada optimasi 3. Sampel terbaik untuk nilai optimasi rasa adalah F1 dan F2 dikarenakan sampel tersebut berada pada wilayah optimasi 2 dimana posisi menunjukan lebih tinggi dari formulasi lainnya.

Hasil uji kesukaan terhadap rasa menunjukan bahwa formula 1 (F1) atau penambahan tepung umbi dahlia dapat diterima sama halnya dengan bubur beras Pandanwangi biasa atau tanpa fortifikan (F2). Pada formula 1 (F1), bubur disukai karena terdapat sentuhan rasa manis yang merupakan perpaduan glukosa dari pati beras serta glukosa dari pati umbi dahlia yang terurai. Saat pati dihidrolisis, akan terjadi pemecahan molekul amilum menjadi komponen penyusunnya seperti glukosa (Purba, 2009).

Formula 2 (F2) disukai karena menyerupai bubur beras pada umumnya. Sedangkan nilai optimasi rata-rata rasa pada F3 menurun. Hal ini disebabkan oleh rasa inulin yang asing bagi lidah panelis sehingga dianggap tidak sesuai dengan selera panelis. Selain itu, rasa inulin yang asing tersebut juga mendominasi keseluruhan rasa bubur sehingga pada formula F4 meskipun rasa bubur dengan tambahan tepung umbi disukai panelis, namun saat dikombinasikan dengan ekstrak inulin rasanya tertutup aroma ekstrak inulin yang kuat.

Penilaian panelis terhadap parameter rasa memiliki selisih yang kecil namun dengan jarak wilayah optimasi yang cukup signifikan. Hal ini menunjukkan bahwa penambahan inulin memengaruhi rasa bubur beras walaupun hanya sedikit dengan hasil akhir masih dapat diterima oleh panelis.

c. Aroma

Setelah membuat model desain penelitian parameter aroma, tahapan selanjutnya yaitu melakukan perhitungan Central Composite Design dan didapatkan grafik seperti berikut:

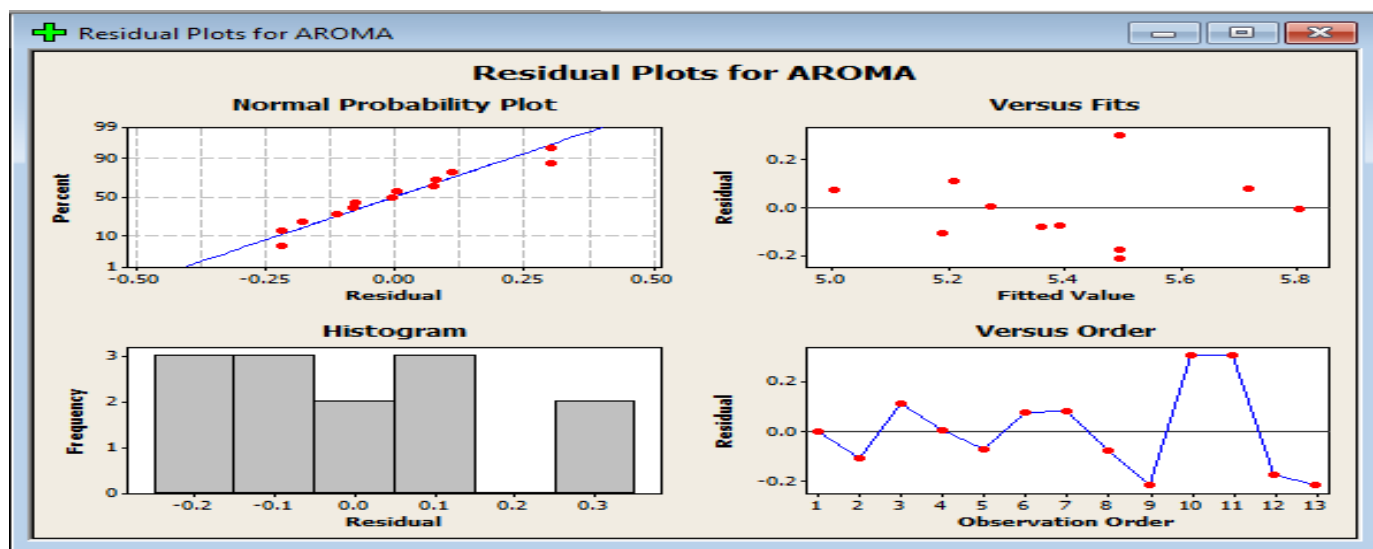

Gambar 9. Grafik perhitungan anova dari parameter aroma (Data primer tahun 2019).

Berdasarkan gambar diatas dapat diketahui bahwa sebaran data untuk aroma tersebar dengan rata dimana titik- titik data mendekati kegaris normal probability sehingga dapat dilakukan perhitungan selanjutnya. 


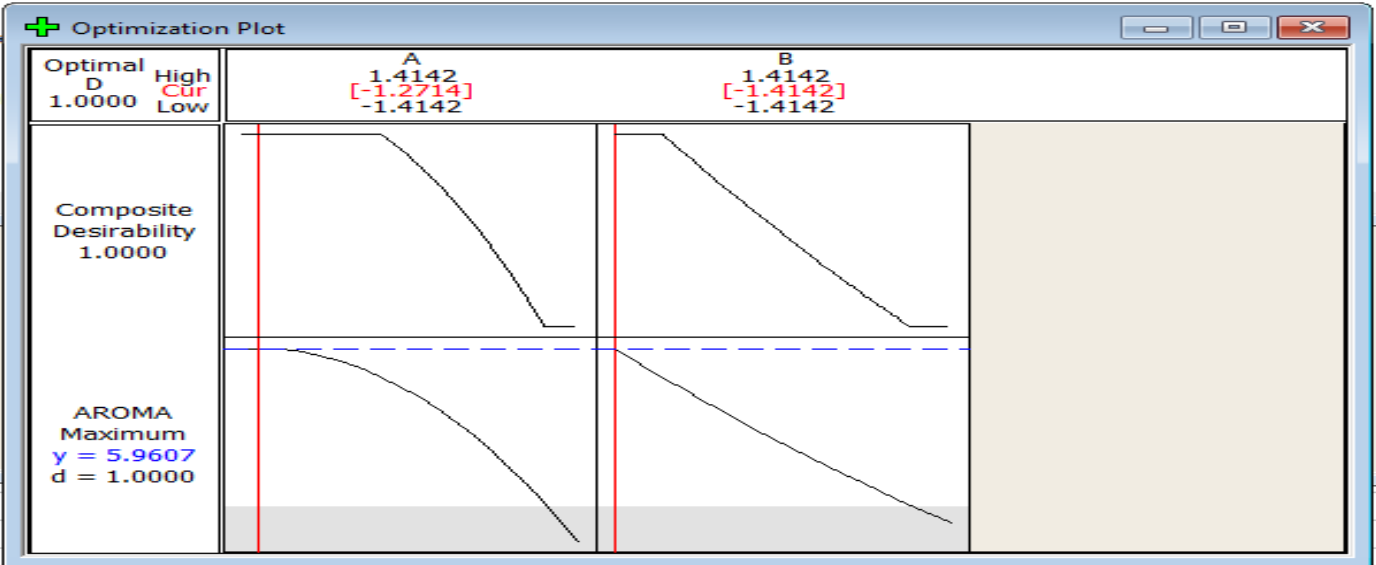

Gambar 10. Nilai optimasi dari parameter aroma (Data primer tahun 2019)

Perhitungan optimasi untuk Gambar 10 didapatkan nilai aroma akan optimal pada nilai 5.9607, dimana akan membentuk suatu parabola yang terbuka kebawah dan mencirikan warna teersebut mempunyai nilai optimal. Fungsi desirability menujukan nilai 1.0 artinya nilai optimasi aroma cukup baik.

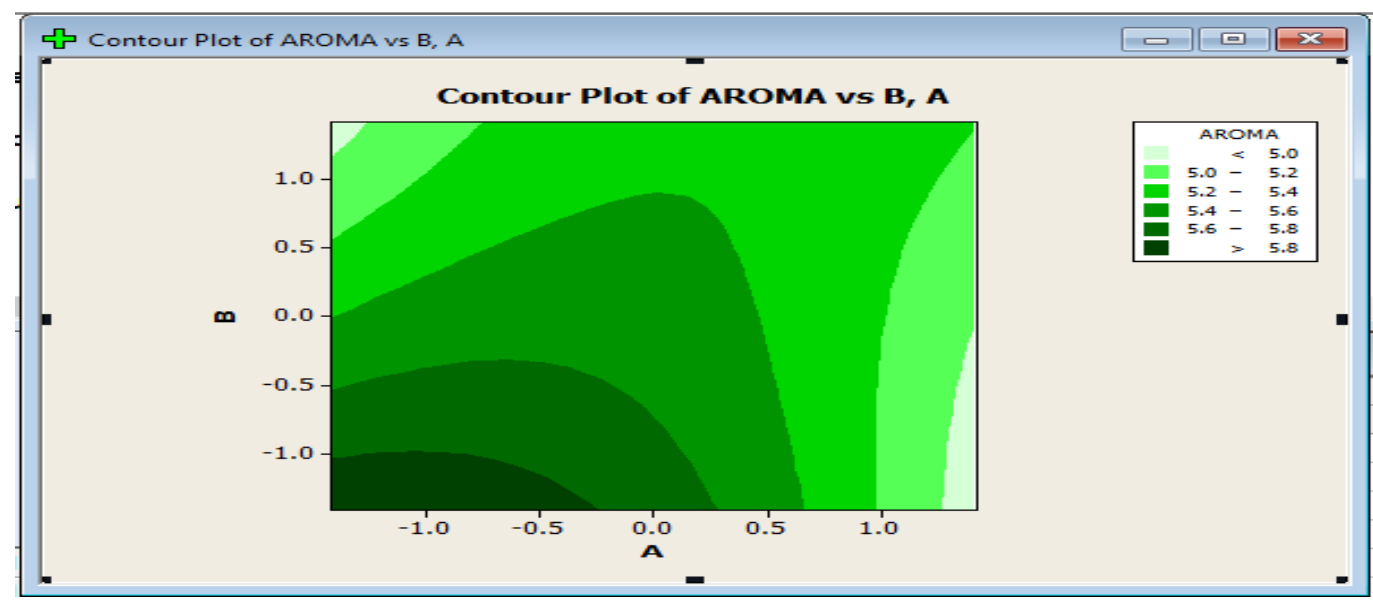

Gambar 11. Contour plot dari parameter aroma (Data primer tahun 2019).

Dari gambar diatas dapat diketahui bahwa batasan wilayah nilai optimasi pada

aroma adalah diantara 5.0-5.8 dengan presentasi bentuk 3D seperti berikut:

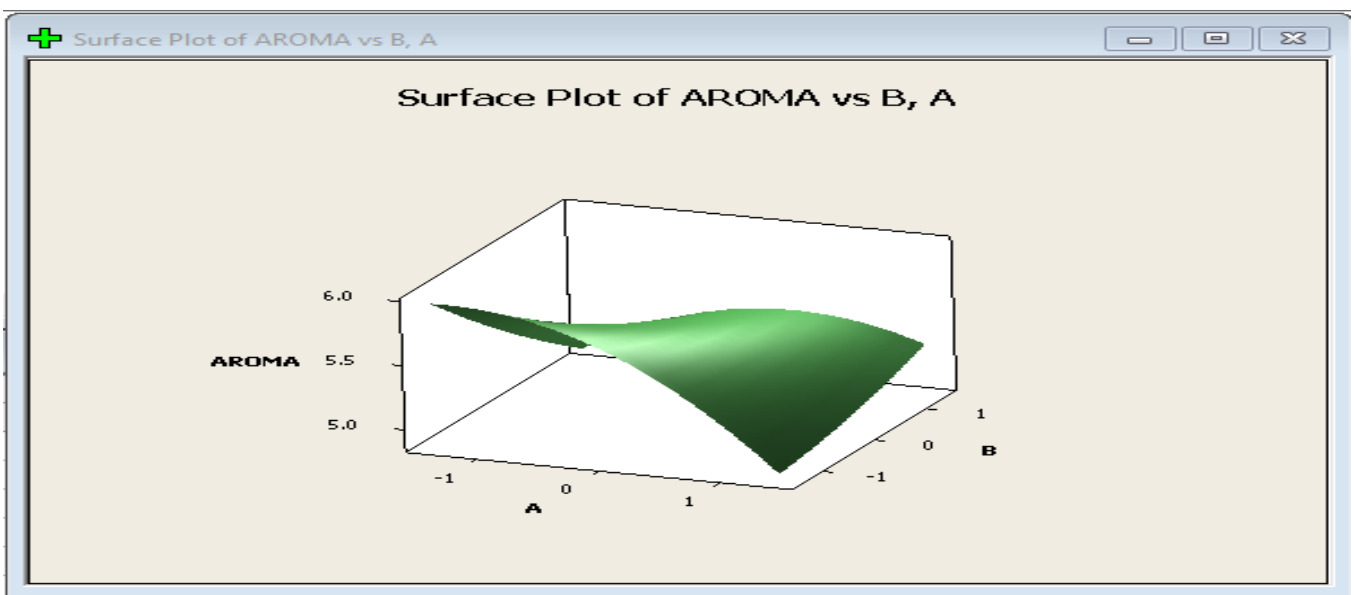

Gambar 12. Surface plot dari parameter aroma (Data primer tahun 2019). 
Dari gambar contour, dapat ditentukan wilayah optimasi berdasarkan nilai rata-rata sampel. Batasan wilayah

Tabel 7. Wilayah Optimasi Rata-Rata Aroma.

\begin{tabular}{cc}
\hline Wilayah Optimasi & Rata-Rata Aroma \\
\hline 1 & $>5.8$ \\
2 & $5.6-5.8$ \\
3 & $5.4-5.6$ \\
4 & $5.2-5.4$ \\
5 & $5.0-5.2$ \\
6 & $<5.0$ \\
\hline
\end{tabular}

Sumber: Data primer (olahan) (2019).

Untuk mendapatkan nilai optimal dari berbagai jenis sampel yang digunakan, maka nilai rata-rata sampel tersebut akan

dimasukan kedalam plot wilayah optimasi dan hasil dapat dilihat pada Tabel 8.

Tabel 8. Nilai Optimasi Rata-Rata Aroma.

\begin{tabular}{ccc}
\hline Sampel & Rata-Rata & Wilayah Optimasi \\
\hline F1 & 5.80 & 2 \\
F2 & 5.08 & 5 \\
F3 & 5.32 & 4 \\
F4 & 5.28 & 4 \\
\hline
\end{tabular}

Sumber: Data primer (olahan) (2019).

*Keterangan:

F1: Beras PW + $10 \mathrm{~g}$ Tepung Umbi

F2: Beras PW

F3: Beras PW + $10 \mathrm{~g}$ Ekstrak Inulin

F4: Beras PW $+5 \mathrm{~g}$ Tepung Umbi $+5 \mathrm{~g}$ Ekstrak Inulin

Dari Tabel 8 dapat diketahui bahwa sampel F1 (Beras Pandanwangi $+10 \mathrm{~g}$ Tepung Umbi) berada pada wilayah optimasi 2. Untuk F2 (Beras Pandanwangi) berada pada wilayah optimasi 5 serta F3 (Beras Pandanwangi + $10 \mathrm{~g}$ Ekstrak Inulin) dan F4 (Beras Pandanwangi $+5 \mathrm{~g}$ Tepung Umbi $+5 \mathrm{~g}$ Ekstrak Inulin) pada optimasi 4.

Hasil uji kesukaan terhadap aroma menunjukkan bahwa formula 1 (F1) atau penambahan tepung umbi dahlia dapat diterima oleh panelis. Ini karena aroma memiliki peran dalam membangkitan selera makan seseorang. Hal ini didukung oleh pendapat dari Hadi dan Siratunnisak (2016) yang menyatakan bahwa aroma dalam suatu produk pangan merupakan faktor penting dalam menentukan tingkat optimasi pada rasa dapat dilihat pada Tabel 7. 


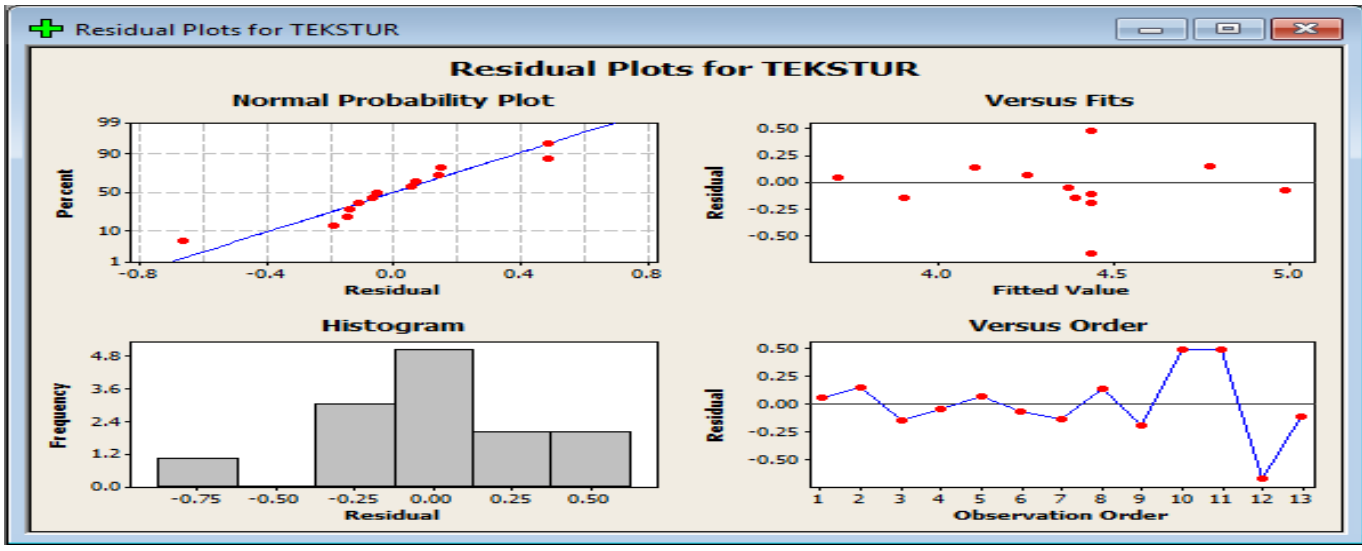

Gambar 13. Grafik perhitungan anova dari parameter tekstur (Data primer tahun 2019).

Berdasarkan pada Gambar 13 mempunyai normal probability yang baik dapat diketahui bahwa sebaran data untuk sehingga data dapat dilakukan tekstur tersebar dengan rata dan perhitungan selanjutnya.

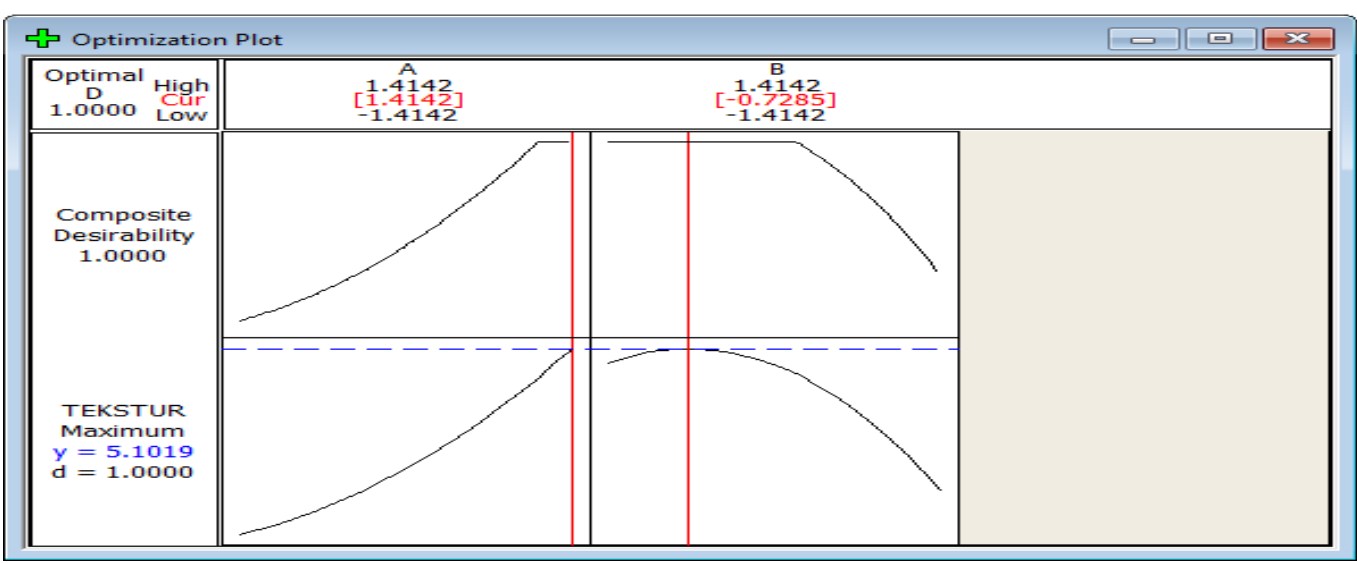

Gambar 14. Nilai optimasi dari parameter tekstur (Data primer tahun 2019).

Perhitungan optimasi diatas menunjukkan bahwa nilai tekstur akan optimal pada nilai 5.1019, dimana akan membentuk suatu parabola yang terbuka kebawah. Fungsi desirability juga

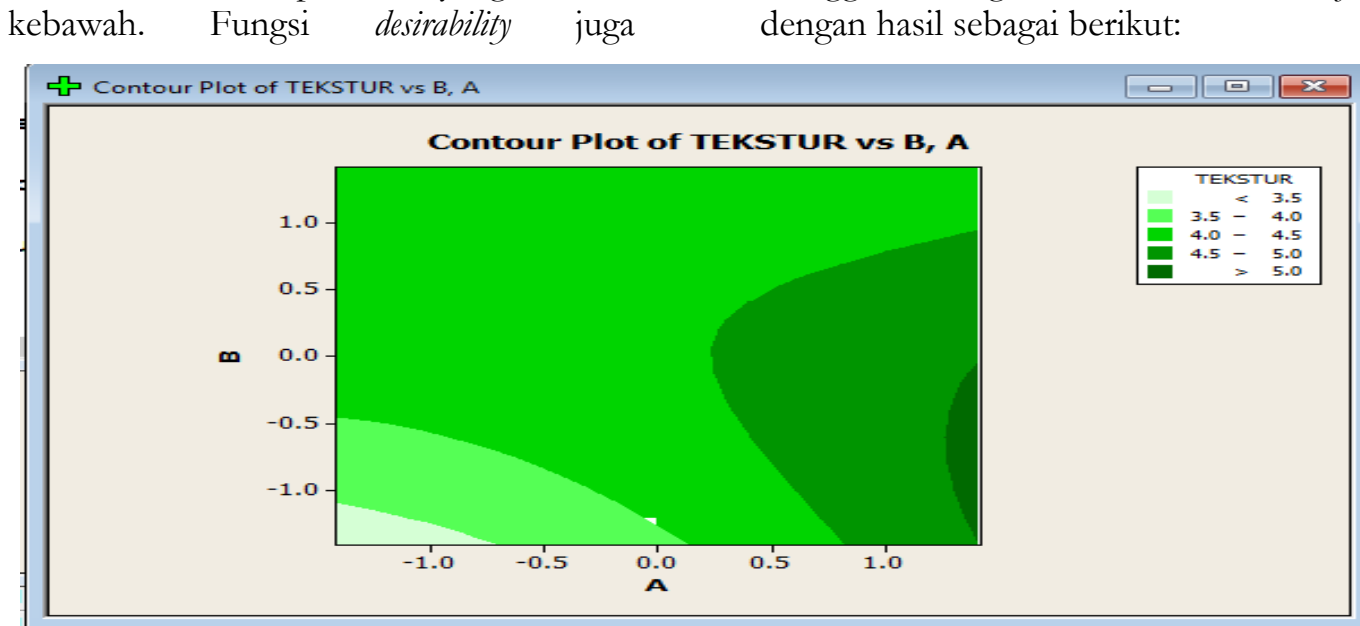

Gambar15. Contour plot dari parameter tekstur (Data primer tahun 2019). menujukkan nilai 1.0 artinya nilai optimasi untuk tekstur cukup baik. Selanjutnya menentukan daerah optimasi menggunakan grafik countour dan surface dengan hasil sebagai berikut: 
Dari Gambar 15 diketahui bahwa batasan wilayah nilai optimasi pada tekstur adalah diantara 3.5-5.0. Batasan wilayah optimasi dapat dilihat pada Tabel 9. Penentuan wilayah optimasi tersebut dapat dipresentasikan dalam bentuk 3D.

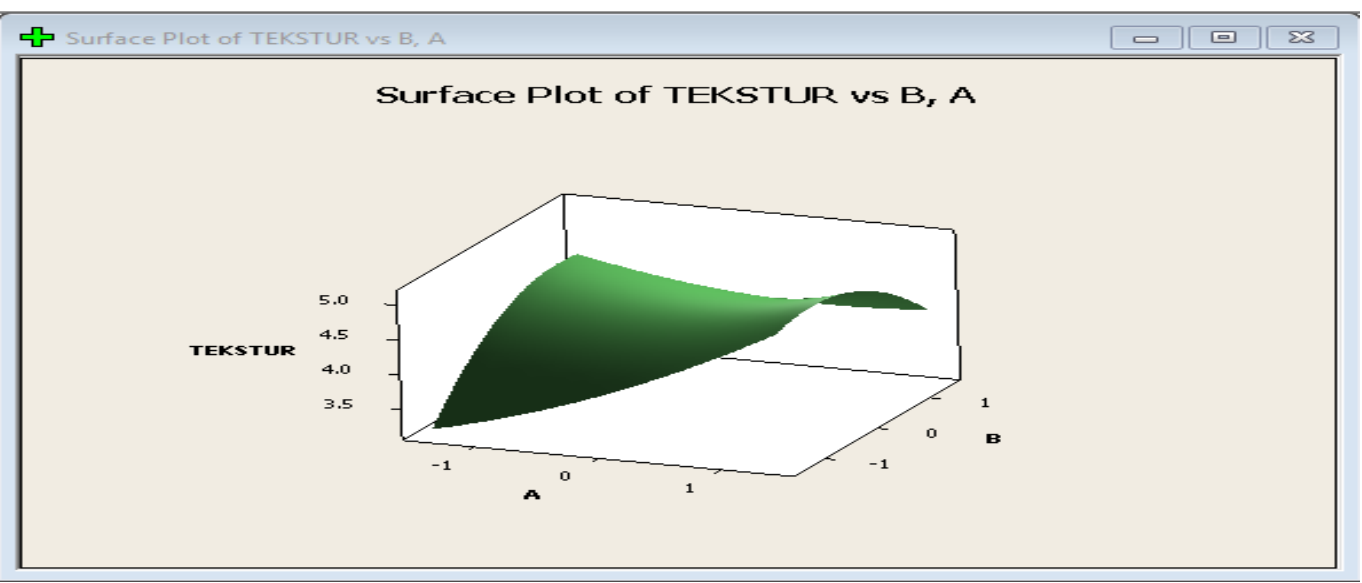

Gambar 16. Surface plot dari parameter tekstur (Data primer tahun 2019).

Tabel 9. Wilayah Optimasi Rata-Rata Tekstur

\begin{tabular}{cc}
\hline Wilayah Optimasi & Rata-Rata Tekstur \\
\hline 1 & $>5.0$ \\
2 & $4.5-5.0$ \\
3 & $4.0-4.5$ \\
4 & $3.5-4.0$ \\
5 & $<3.5$ \\
\hline
\end{tabular}

Sumber: Data primer (olahan) (2019).

Untuk mendapatkan nilai optimal dari berbagai jenis sampel yang digunakan, maka nilai rata-rata sampel tersebut akan

Tabel 10. Nilai Optimasi Rata-Rata Tekstur.

\begin{tabular}{ccc}
\hline Sampel & Rata-Rata & Wilayah Optimasi \\
\hline F1 & 3.76 & 4 \\
F2 & 4.92 & 2 \\
F3 & 4.24 & 3 \\
F4 & 4.32 & 3 \\
\hline
\end{tabular}

Sumber: Data primer (olahan pribadi) (2019).

*Keterangan:

F1: Beras PW + $10 \mathrm{~g}$ Tepung Umbi

F2: Beras PW

F3: Beras PW $+10 \mathrm{~g}$ Ekstrak Inulin

F4: Beras PW $+5 \mathrm{~g}$ Tepung Umbi $+5 \mathrm{~g}$ Ekstrak Inulin

Dari Tabel 10 dapat diketahui bahwa F1 (Beras Pandanwangi + $10 \mathrm{~g}$ Tepung Umbi) berada pada wilayah optimasi 4 dan merupakan formula yang paling tidak disukai panelis. Selanjutnya F2 (Beras Pandanwangi) berada pada wilayah optimasi 2. Sedangkan F3 (Beras Pandanwangi $+10 \mathrm{~g}$ Ekstrak Inulin) dan F4 (Beras Pandanwangi $+5 \mathrm{~g}$ Tepung dimasukan kedalam plot wilayah optimasi dan hasil dapat dilihat pada Tabel 10 .
Umbi +5 g Ekstrak Inulin) berada pada wilayah optimasi yang sama yaitu 3 .

Hasil uji kesukaan terhadap tekstur menunjukkan bahwa F2 merupakan formula yang paling disukai. Hal ini karena formula tersebut menyerupai bubur beras pada umumnya. Bubur dengan penambahan umbi dahlia kurang disukai panelis karena terdapat sedikit 
sentuhan lengket pada bubur. Hal itu dikarenakan umbi dahlia mengandung serat pangan yang tergelatinisasi dengan suasana alkali. Meskipun lengket, serat makan yang diperoleh dari proses gelatinisasi tersebut merupakan sumber pangan fungsional untuk anti kolestrol dan anti konstipasi (Susilowati et al., 2015).

\section{Penentuan Sampel Terbaik}

Berdasarkan nilai optimasi yang didapatkan dari peroleh nilai rata-rata maka dapat diketahui satu sampel terbaik.

\begin{tabular}{ccccccccc}
\hline \multirow{2}{*}{ Sampel } & \multicolumn{2}{c}{ Warna } & \multicolumn{2}{c}{ Rasa } & \multicolumn{2}{c}{ Aroma } & \multicolumn{2}{c}{ Tekstur } \\
\cline { 2 - 9 } & $\begin{array}{c}\text { Rata- } \\
\text { Rata }\end{array}$ & Optimasi & $\begin{array}{c}\text { Rata- } \\
\text { Rata }\end{array}$ & Optimasi & $\begin{array}{c}\text { Rata- } \\
\text { Rata }\end{array}$ & Optimasi & $\begin{array}{c}\text { Rata- } \\
\text { Rata }\end{array}$ & Optimasi \\
\hline F1 & 3.72 & 6 & 4.40 & 2 & 5.80 & 2 & 3.76 & 4 \\
F2 & 5.52 & 3 & 4.40 & 2 & 5.08 & 5 & 4.92 & 2 \\
F3 & 3.64 & 6 & 4.12 & 6 & 5.32 & 5 & 4.24 & 3 \\
F4 & 3.84 & 6 & 4.32 & 3 & 5.28 & 4 & 4.32 & 3 \\
\hline
\end{tabular}

Formulasi terbaik untuk warna adalah F2 yaitu bubur beras Pandanwangi tanpa penambahan umbi dahlia karena warnanya yang putih bersih sesuai dengan persepsi panelis mengenai bubur beras pada umumnya.

Pada parameter rasa, F1 dan F2 berada pada wilayah optimasi yang sama yaitu 2, namun dengan kandungan inulin didalam tepung umbi dahlia, menjadikan F1 mendapat nilai tambah. Selain itu F1 menunjukkan bahwa bubur beras yang difortifikasi dengan tepung umbi dahlia dapat diterima panelis sama halnya dengan bubur beras Pandanwangi biasa (F2). Karena itu, formulasi terbaik untuk rasa adalah formula F1.

Formulasi terbaik untuk aroma adalah F1 karena formula tersebut berada pada wilayah yang tinggi dibandingkan formula lainnya yaitu pada wilayah optimasi 2. Sedangkan untuk tekstur, F2 merupakan formula yang paling disukai panelis karena karakter tekstur yang masuk dalam mulut menyerupai bubur beras pada umumnya.

\section{KESIMPULAN}

Berdasarkan uji organoleptik, bubur instan beras Pandanwangi tanpa fortifikan (F2) merupakan formula yang dapat diterima panelis dari segi warna dan tekstur karena karakteristiknya yang mirip dengan bubur beras pada umumnya, namun formula tersebut tidak mengandung tambahan zat gizi apapun sehingga tidak masuk dalam kategori makanan fungsional.

Formula yang dapat diterima panelis untuk parameter aroma yaitu F1. Aroma yang berasal dari tepung umbi dahlia menambah citarasa sehingga memberi nilai lebih pada F1. Sedangkan untuk rasa, formula yang dapat diterima panelis adalah F1 dan F2, namun meskipun keduanya berada pada wilayah optimasi yang sama, dalam F1 terdapat fortifikan inulin dari tepung umbi dahlia sedangkan F2 murni hanya menggunakan beras Pandanwangi saja sehingga tidak masuk kategori makanan fungsional. Oleh karena itu, dapat disimpulkan bahwa formulasi terbaik untuk makanan fungsional bubur instan beras Pandanwangi yang diterima panelis dalam penelitian ini adalah F1.

\section{DAFTAR PUSTAKA}

Arsa, M. 2016. Proses Pencoklatan (Browning Process) pada Baban Pangan. Jurusan Kimia Fakultas Matematika dan Ilmu Pengetahuan Alam Universitas Udayana. Denpasar.

Desfitri, E.R., Mezoti, A.A., Sundari, E., dan Martynis, M. 2015. Optimasi Ekstraksi Inulin dari Umbi Dahlia dengan Menggunakan Pelarut Etanol. E-Jurnal Bung Hatta 5 (4). 
Estiasih dan Ahmadi. 2009. Teknologi Pengolahan Pangan. PT Bumi Aksara: Jakarta.

Hadi, A., dan Siratunnisak. 2016. Pengaruh Penambahan Bubuk Coklat Terhadap Sifat Fisik, Kimia, dan Organoleptik Minuman Instan Bekatul. Aceh Nutrition Journal 1 (2): 121-129.

Irmayanti, W.O., Hermanto, dan Asyik, N. 2017. Analisis Organoleptik dan Proksimat Biskuit Berbahan Dasar Ubi Jalar dan Kacang Hijau. Jurnal Sains dan Teknologi Pangan 2 (2): 412-424.

Mangunwidjaja, D., Rahayuningsih, M., dan Suparwati, R. 2014. Pengaruh Konsentrasi Enzim dan Waktu Hidrolisis Enzimatis Terhadap Mutu Fruktooligosakarida dari Inulin Umbi Dahlia (Dablia pinnata). E-Jurnal Agroindustri Indonesia 3 (1).

Midayanto, D., dan Yuwono, S. 2014. Penentuan Atribut Mutu Tekstur Tahu untuk Direkomendasikan sebagai Syarat Tambahan dalam Standar Nasional Indonesia. Jurnal Pangan dan Agroindustri 2 (4): 259267.

Palupi, H.T. 2015. Pengaruh Konsentrasi Ekstrak Daun Cincau Hijau (Cycle barbata L. Miers) dan Suhu Ekstraksi Terhadap Karakteristik Mie Basah. Jurnal Teknologi Pangan 6 (1).

Purba, E. 2009. Hidrolisis Pati Ubi Kayu (Manibot Esculenta) dan Pati Ubi Jalar (Impomonea batatas) menjadi Glukosa secara Cold Process dengan Acid Fungal Amilase dan Glukoamilase. Universitas Bandar Lampung. Lampung.
Radojkovic, M., Zekovic, Z., Jokic, s., dan Vidovic, S. 2012. Determination of Optimal Extraction Parameters of Mulberry Leaves Using Response Surface Methodology (RSM). Romanian Biotechnological Letters 17 (3).

Sundari, E., Rahmilaila, E., Martynis, M., dan Erti Praputri. 2014. Identifikasi dan Kondisi Ekstraksi Inulin Dari Umbi Dahlia di Sumatera Barat. Prosiding SNSTL I: 2356-4938.

Susilowati, A., Dewi, P., dan Sujarwo. 2015. Karakteristik Serat Inulin (Dietary Fiber) dari Umbi Dahlia (Dablia spp. L.) Lokal Melalui Proses Gelatinisasi sebagai Pangan Fungsional. Prosiding Seminar Nasional XX Kimia, Jaringan Kerjasama Kimia Indonesia dan Yayasan Media Kimia Utama.

Trihaditia, R. 2015. Penentuan Formulasi Optimum Pada Pembuatan Minuman Fungsional Rambut Jagung Dengan Penambahan Madu dan Jeruk Nipis Menggunakan Metode RSM (Response Surface Method). Tesis. Universitas Pasundan. Bandung.

Widowati, Sunarti, T.C., dan Zaharani, A. 2005. Ekstraksi, Karakteristik, dan Kajian Potensi Prebiotik Inulin dari Umbi Dablia (Dablia pinnata L.). Seminar Rutin Puslitbang Tanaman Pangan Bogor.

Widowati. 2009. Tepung Aneka Umbi Sebuah Solusi Ketabanan Pangan. Tabloid Sinar Tani Edisi 6-12, No.3302 Tahun XXXIX. Balai Besar Penelitian dan Pengembangan Pascapanen Pertanian. Bogor. 